\title{
ON THE HABITS OF TURRITELLA COMMUNIS RISSO
}

\author{
By C. M. Yonge, F.R.S. \\ From the Marine Biological Station, Millport, and the Department of Zoology, \\ University of Glasgow
}

(Text-fig. I)

\section{INTRODUCTION}

In his account of the food of the bottom fauna around Plymouth, Hunt (1925) separated Turritella communis and Aporrhais pes-pelecani from the other Gastropoda as deposit-feeders. He always found roughly sorted bottom material in their stomachs.

$A$. pes-pelecani was subsequently shown to be specialized for burrowing into muddy gravel (Yonge, 1937). The proboscis makes mucus-lined inhalant and exhalant passages to the surface and then proceeds to collect, from under the surface, detritus of vegetable origin by means of the small grasping radula.

T. communis, however, feeds in a very different manner. Graham (I938) has shown that it is a ciliary feeder. Owing to its mud-burrowing habit, it differs from the other ciliary feeding prosobranchs (for details of which see Yonge, 1938), most notably in the possession of a curtain of tentacles, the larger of them pinnate, which guard the entrance into the inhalant chamber. They effectively prevent the entrance of large particles into the mantle cavity. Graham gives a detailed account of the structure and function of the organs of feeding and digestion. He did not observe the animal in its natural habitat, and it was to fill this gap in knowledge that the present observations were made.

This work was carried out at the Marine Biological Station, Millport, and it is a pleasure to acknowledge the assistance received from the Director, Mr R. Elmhirst, and from the staff of the Station.

\section{OBSERVATIONS}

Specimens of $T$. communis were obtained from thick muddy gravel (which also contained A. pes-pelecani) in Balloch Bay, Isle of Cumbrae, at depths of from 9 to $I 2$ fathoms. Samples of the bottom material were collected at the same time and the behaviour of the animals subsequently examined in the laboratory.

When placed on its normal substratum, Turritella soon protrudes the relatively small foot, rights itself and proceeds slowly to work its way diagonally down, at an angle of some $10^{\circ}$ to the horizontal, into the mud. It moves in a series of slow and laborious jerks, turning from side to side as it works its way into the substratum. It thus comes to lie in a groove with a slight mound in front beneath which the larger whorls of the shell are buried. 
Eventually the animal completely disappears under the surface, and then movement usually ceases. Unlike Aporrhais which, owing to exhaustion of the local supply of detritus, frequently changes its position, Turritella remains stationary for long periods (up to a week under observation in the laboratory), and possibly does so indefinitely under natural conditions unless disturbed. This stationary life is typical of a ciliary feeder.

An inhalant depression appears in the mud in front of the left side of the mantle cavity (see Fig. I). This is made by the foot $(F T)$ which bends over and pushes the mud to the right where it forms a low mound $(M)$ in front of

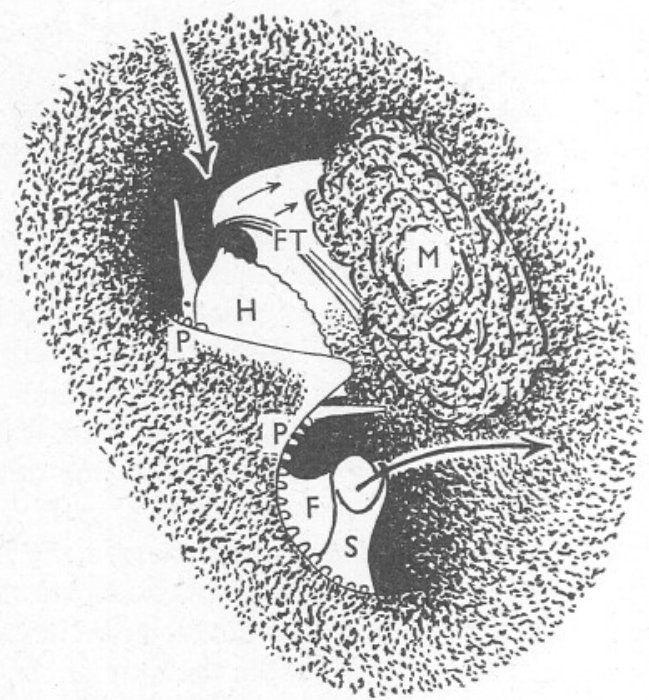

Fig. I. Turritella communis, appearance when foot and head are extruded in connexion with clearance of the inhalant depression. $\times 5 . F$, flap at end of the right fold of the food groove; $F T$, foot; $H$, head; $M$, mound of mud consolidated with mucus from the pedal gland; $P$, pallial tentacles; $S$, siphonal process forming exhalant siphon with $F$. Large arrows indicate direction of inhalant and exhalant currents, small arrows of ciliary currents on the sole of the foot.

the head. Backwardly beating cilia on the sole of the foot aid in this and the mud is partly consolidated with mucus from the pedal gland which prevents it from falling back into the depression. After this process is completed, the foot and head are withdrawn and not again protruded unless mud falls into the inhalant depression and this has again to be cleared.

To the right of the mound is a smaller, shallower depression formed initially by expulsion of water from the right, exhalant side of the mantle cavity. Out of this depression there projects the upwardly directed tubular exhalant siphon. These depressions, the mound between them, and the tip of the siphon are the only indications of the presence of the animal when once it is completely buried. 
The flow of water through the inhalant aperture into the mantle cavity is very gentle owing to the width of the opening, and the surrounding mud is not disturbed. The animal is very sensitive, closing the mantle cavity when even small amounts of fine mud or of carmine are introduced into the inhalant current. The guarding curtain of pinnate tentacles is normally hidden from view, but an outer row of simple pallial tentacles $(P)$ which curl round the margin of the shell is visible. Similar tentacles fringe the exhalant opening.

Graham states that he does not, on the basis of his work, suggest that Turritella is an exclusively ciliary feeder. He considers it possible that the radula may also be capable of collecting food in the manner of a typical gastropod. But, during the present observations, no evidence was obtained that the mouth receives any material other than what comes to it from the ctenidium by way of the deep food groove on the right side of the head, as described by Graham. The reduction of the odontophore and of the salivary glands, noted by him, strongly supports the view that Turritella is an exclusively ciliary feeder.

Graham describes two folds to the right of the head. The inner $(F)$ represents the forward extension of the fold which bounds the right side of the deep food-groove, and it enlarges terminally 'to form a semi-elliptical flap of tissue set in a vertical position'. The outer one $(S)$ arises more ventrally, is horseshoeshaped and curved upwards. Graham writes of the apical portions as 'kept curled over each other so as to form an incomplete "siphon". As he notes, the presence of an exhalant siphon in the prosobranchs is unique. Reference to Fig. I will show that actually this siphon is formed by a combination of both of these folds, and not merely by the outer one. Their margins overlap so as to form an effectively complete tubular siphon through which water is expelled well above the surface of the mud, which is thus not disturbed. The presence of this siphon is clearly correlated with the mud-burrowing habit. The ovalshaped faecal pellets are also expelled for some little distance, usually to the other side of the exhalant depression, through the siphon. But this expulsion only follows partial withdrawal of the animal which, by reducing the size of the mantle cavity, causes a more powerful exhalant current.

The above observations confirm and extend those of Hunt and of Graham on the food and feeding of $T$. communis. The animal is a highly specialized burrower in stiff mud containing a fair admixture of shell gravel and small stones. When placed on a substratum of fine silty mud, such as that in which such species as Abra abra and, in more estuarine water, Macoma baltica occur, it finds difficulty in maintaining the inhalant depression while the foot becomes clogged in this medium. The same difficulty was previously noted in the case of Aporrhais pes-pelecani although A. serresiana is adapted for life in such a substratum (Yonge, 1937). 


\section{SUMMARY}

Turritella communis is a highly specialized burrower in gravelly mud. Once buried, it moves little in correlation with its apparently exclusively ciliary feeding habit. An inhalant depression in the mud is made by lateral movements of the foot. There is a unique exhalant siphon constituted by two overlapping folds, and through this water and faecal pellets are expelled without disturbing the surrounding mud.

\section{REFERENCES}

GraHAM, A., I938. On a ciliary process of food-collecting in the Gastropod Turritella communis Risso. Proc. Zool. Soc, Lond. (A), Vol. cvIII, pp. 453-63.

HunT, O. D., I925. The food of the bottom fauna of the Plymouth fishing grounds. fourn. Mar. Biol. Assoc., Vol. xIII, pp. 560-99.

Yonge, C. M., I937. The biology of Aporrhais pes-pelecani (L.) and A. serresiana (Mich.). Fourn. Mar. Biol. Assoc., Vol. xxI, pp. 687-704.

I938. Evolution of ciliary feeding in the Prosobranchia, with an account of feeding in Capulus ungaricus. Fourn. Mar. Biol. Assoc., Vol. xxII, pp. 453-68. 